\title{
地域在住女性高齢者の最速歩行時の歩行パラメータと 身体機能との関連
}

\section{Relationship between Fast Walking Parameters and Physical Functions in Community Dwelling Elderly Woman}

\author{
辻井 優衣, 村尾 太郎, 岩瀬 弘明, 白岩加代子 \\ 安彦 鉄平, 堀江 淳, 内藤 紘一, 村田伸
}

Yui Tsujii, Tarou Murao, Hiroaki Iwase, Kayoko Shiraiwa

Teppei Abiko, Jun Horie, Kouichi Naitou, Shin Murata

\begin{abstract}
要 旨：本研究の目的は, 地域在住女性高齢者における最速歩行時の歩行パラメータと身 体機能との関連を明らかにすることである。体力測定会に参加した地域在住女性高齢者96

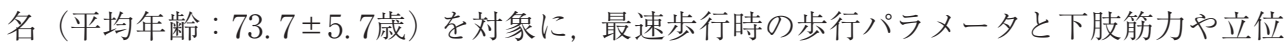
バランスなどの身体機能を計測した。重回帰分析の結果，歩行パラメータに独立して関係 する因子として抽出された項目は, 最大歩行速度では, trail making test (TMT), 30second chair-stand test (CS-30), 開眼片脚立位時間の 3 項目であった。歩幅とストライ ドの影響因子はともに長座体前屈距離，身長，CS-30の 3 項目，両脚支持時間は上体起こ し，年齢，体重の 3 項目であった。歩行角度は身長とCS-30の 2 項目であった。これらの ことから, 地域在住女性高齢者の下肢筋力と柔軟性, バランス能力, および注意機能を改 善することで, 歩行能力の維持・向上を図れる可能性が示唆された。
\end{abstract}

キーワード：地域在住女性高齢者, 歩行パラメータ, 身体機能

\begin{abstract}
This study examined the relationship between fast walking parameters and physical functions in community dwelling elderly woman. The measurement of physical functions, such as gait parameters, the lower limb muscle strength, and standing balance, was performed in 96 elderly females (mean age: $73.7 \pm 5.7$ ), who lived in a community and participated in a physical fitness measurement event. Multiple regression analysis revealed that the trail making test (TMT) and 30-second chair-stand test (CS-30) scores and duration of standing on one leg with the eyes open influence the maximum walking speed; the sit-and-reach test score, height, and CS-30 score influence both the step length and stride; the number of sit-ups, age, and weight influence the duration of the double-support period; and the height and CS-30 score influence the gait angle. Based on this, it may be possible to maintain/improve the walking ability of elderly females living in communities by enhancing their lower limb muscle strength, flexibility, balance, and attention.
\end{abstract}

Key words: community dwelling elderly woman, walking parameters, physical functions

受付日：2017年10月24日，採択日：2018年 6 月14日

京都橘大学健康科学部理学療法学科：=607-8175 京都府京都市山科区大宅山田34 TEL：075-571-1111

Department of Physical Therapy, Faculty of Health Science, Kyoto Tachibana University

E-mail :murata-s@tachibana-u.ac.jp 


\section{I 、はじめに}

高齢化が進行する近年, 加齢による運動能力の低下 に人々の関心が集まっている。高齢者が自立した生活 を営む上で移動能力は必要不可欠である。歩行速度が 遅い高齢者は転倒リスクが高く ${ }^{1)}$ ，将来「閉じこもり」 老人となりやすいことが報告 2 されれており, 歩行速度 を維持・改善することは, 高齢者の quality of life （QOL）の向上に繋がると考えられる。

高齢者を対象とした先行研究では, 歩行パラメータ の中でもとくに歩行速度に着目した研究が多い。大杉 $ら^{3}$ は最速歩行時の歩行パラメータと身体機能との関 係について検討し, 最大歩行速度は握力や下肢筋力, バランス能力など種々の身体機能と関連することを報 告している。

高齢者の歩行能力低下は，加齢による筋力低下やバ ランス能力の低下に起因することは周知の事実である。 しかし, 歩行は筋力やバランス能力の他にも注意機能 などが複合的に機能することで遂行される動作である ため, 先行研究 ${ }^{3)}$ ような単変量解析では加齢による 筋力低下や柔軟性の低下など, 複数の因子が歩行速度 に影響を及ぼすといった交絡関係を調整することはで きない。高齢者の歩行能力を維持・改善するためには, 歩行パラメータに独立して関連する身体機能の因子を 明らかにする必要がある。

そこで，本研究は地域在住高齢者の最速歩行時の歩 行パラメータと身体機能との関連について, 多変量解 析を用いて検討することとした。

\section{II. 対象と方法}

\section{1. 対 象}

対象はY市に居住し，Y市で実施している介護予 防・生きがい対策事業である「生きがいサークル」に 登録している高齢者のうち，Y市と著者所属大学との 連携事業である健康調査に参加した高齢者を対象とし た。なお，参加者が少なかった男性，杖歩行の者は除 外し, 女性高齢者 96 名を解析対象とした。対象者の平 均年齢は73.7 \pm 5.7 歳, 身長は $150.8 \pm 5.9 \mathrm{~cm}$, 体重は $49.6 \pm 8.7 \mathrm{~kg}$ (平均土標準偏差) であった。対象者に は研究の趣旨と内容, 得られたデー夕は研究以外で使 用しないこと，および個人情報の漏洩に注意すること について説明し，理解を得た上で協力を求めた。また， 研究への参加は自由であり, 被験者にならなくとも不 利益にならないことを口頭と書面で説明し同意を得た。 な㧍, 本研究は京都橘大学の研究倫理委員会に承認を
得て行った（承認番号14- 5 ）。

\section{2. 方 法}

歩行パラメータは, 最速歩行時の歩行速度, 歩幅, ストライド，立脚時間，遊脚時間，両脚支持時間，歩 隔，歩行角度，つま先角度の 9 項目とした。最大歩行 速度は，歩行能力の評価指標のみならず，高齢者の予 後予測としても有用であり, 健常者では下肢筋力やバ ランス能力の影響を受ける4)。そのため, 対象者には 最大速度での歩行を指示した。身体機能の評価は，体 幹筋力として上体起こし, 上肢筋力として握力, 下肢 筋力として大腿四頭筋筋力, 足趾把持力, 30 秒椅子立 ち上がりテスト (30-second chair-stand test: CS-30) の 3 項目，柔軟性として長座体前屈距離，バランス機 能評価として開眼片脚立位時間を測定した。また，注 意機能を Trail Making Test（TMT）で評価した。

歩行パラメータの測定には，シート式足圧設置足跡 計測器（ウォーク way MW-1000，アニマ社製）を用 いた。ウォーク way はシート上を歩行することによ り，ヒトの歩行解析に必要な時間因子である歩行速度 や立脚時間，空間因子であるストライドや歩行角など の歩行パラメータを収集する機器である。測定する シートは $800 \mathrm{~mm} \times 2,400 \mathrm{~mm}$ の薄型シート形状 で，14,000ポイントのセンサーが埋め达まれている。 シート前後の $3 \mathrm{~m}$ を助走路と追走路とし, 計 $8.4 \mathrm{~m}$ を 歩行区間とした。対象者には「できるだけ速く歩いて ください」と口頭指示を与え，歩行区間を最大歩行速 度で歩行してもらい, 中央 $2.4 \mathrm{~m}$ のシート上の歩行パ ラメータを測定した。分析に用いた歩行パラメータは, 歩行速度 $(\mathrm{cm} / \mathrm{sec})$, 歩幅 $(\mathrm{cm})$, ストライド $(\mathrm{cm})$, 立脚時間 $(\mathrm{sec})$, 遊脚時間 $(\mathrm{sec})$, 両脚支持時間 $(\mathrm{sec})$, 歩隔 $(\mathrm{cm})$, 歩行角度 $\left({ }^{\circ}\right)$, つま先角度 $\left({ }^{\circ}\right)$ とし た。歩行角度は, 歩行中の身体線に対しての足部の角 とし，つま先角度とは踵から進行方向への直線に対し てつま先と踵を結んだ線が角度とした。なお，立脚時 間，遊脚時間，立脚支持時間，歩幅，歩隔，歩行角度， つま先角度については左右の平均值を代表值とした。

上体起こしの測定は，文部科学省新体力テストの実 施要項 ${ }^{5}$ に従い，測定肢位は背臥位とし，両上肢を胸 の前で組み, 両膝関節は $90^{\circ}$ 屈曲位の姿勢から, 両肘 が両大腿部に接触するまで上体を起こすよう指示した。 その際，検者は対象者の両膝を固定した。測定は30秒 間で可能な限り繰り返させ，その回数（回）を記録し た。 
握力の測定には，デジタル式握力計(T.K.K. 5401, 竹 井機器工業製）を使用した。文部科学省新体力テスト の実施要項 ${ }^{5}$ に従い，示指の近位指節間関節が約 $90^{\circ}$ になるように握り幅を調節した。測定肢位は立位とし 両上肢を体側に下垂した状態で最大努力にて握りしめ るように指示した。測定は, 左右 2 回ずつ測定し, そ の最大値（kg）を代表值として採用した。

大腿四頭筋筋力の測定には，ハンドヘルドダイナモ メーター $(\mu$-TasF-1，アニマ社製）を使用した。加 藤ら ${ }^{6}$ の方法に準じて, 椅子座位にて椅子の支柱にべ ルトを固定し，下腿下垂位での等尺筋力を測定した。 対象者は, 体幹垂直位, 膝関節 $90^{\circ}$ 屈曲位, 両上肢は 胸の前で組み, センサーパッドを下腿の遠位部にあて 測定した。測定中はセンサーパッドのずれを防止する ために検者が前方で固定した。測定は, 左右 2 回ずつ 測定し，その最大值（kg）を代表值として採用した。

足趾把持力は, 足趾筋力測定器 II (T.K.K3364b, 竹井機器工業製）を使用した。相馬ら の方法に準じ て, 測定肢位は端座位とし体幹垂直位, 膝関節 $90^{\circ}$ 屈 曲位, 両上肢は胸の前で組み, 把持バーを足趾で把持 できるように調節し実施した。測定は, 左右 2 回ずつ 測定し，その最大值（kg）を代表值として採用した。

CS-30の測定は，中谷ら ${ }^{8}$ の方法に従い, 时掛と背 もたれのない椅子を使用し，両上肢は胸の前で組んだ 椅子座位で実施した。その際, 足底がしっかり床に接 することに留意した。開始の合図で座位姿勢から膝関 節完全伸展位するように立位姿勢になり再び着座する までを 1 回とし，30秒間の実施回数（回）を記録した。 なお，立ち上がり途中で30秒を経過した場合は測定回 数に含めなかった。

長座体前屈距離の測定は, デジタル式長座体前屈測 定機器（T.K.K. 5412，竹井機器工業製）を使用した。 文部科学省新体力テストの実施要項 ${ }^{5}$ に従い, 壁に背 中と慰部をしっかりとつけた長座位姿勢から前屈した 時の最大到達距離を測定した。測定は, 2 回測定し, その最長距離（cm）を代表値として採用した。

開眼片脚立位時間 ${ }^{9}$ の測定は，対象者は裸足となり， 両上肢は軽く体側につけた開眼片脚立位で姿勢保持で きる時間について 120 秒を上限としてストップウォッ チを使用して測定した。なお，中止基準は上肢が体幹 から離れる，支持脚の位置が動く，または対側の足部 が床に接触する場合とした。測定は, 左右 2 回ずつ測 定し，その最長時間（sec）を代表值として採用した。 $\mathrm{TMT}^{10}$ の測定は，TMT-A を実施した。紙面上にラ
ンダムに配置された 1 から 25 までの数字を小さい方か ら順に線で結んでいく。評価は開始から順にすべてを 結ぶまでの時間をストップウォッチで測定し，その測 定時間（sec）を記録した。なお，対象者には施行手 順を修得させるために, 練習用 TMT を用いて十分に 実施できることを確認した後, 測定を 1 回行い，代表 值とした。

\section{3. 統計処理}

各歩行パラメータと身体機能との関連を明らかにす るために, 従属変数を歩行速度, 歩幅, ストライド, 立脚時間, 遊脚時間, 両脚支持時間, 歩隔, 歩行角度, つま先角度の 9 項目, 独立変数を上体起こし, 握力, 大腿四頭筋筋力, 足指把持力, CS-30, 長座体前屈距 離, 開眼片脚立位時間, TMT とした重回帰分析ステッ プワイズ法で解析した。統計ソフトにはSPSS Statistics Version22.0 (IBM 社製)を用い，有意水準を $5 \%$ とした。

\section{III. 結 果}

表 1 に被験者 96 名の属性, 歩行パラメー夕, 身体機 能に関する測定項目の平均值と標準偏差を示す。

重回帰分析に抢いて，各歩行パラメー夕に影響を及 ぼす因子として抽出された項目を表 2 に示す。最大歩 行速度の影響因子は TMT, CS-30, 開眼片脚立位時間 の 3 項目, 歩幅とストライドの影響因子はともに長座 体前屈距離，身長，CS-30の 3 項目，両脚支持時間は 上体起こし, 年齢, 体重の 3 項目, 歩行角度は身長と CS-30であった。なお, 立脚時間, 遊脚時間, 歩隔, つま先角度の 4 項目については，影響因子として抽出 された項目は認められなかった。

\section{IV. 考 察}

本研究は, 地域在住女性高齢者の最速歩行時の歩行 パラメータと身体機能との関連について検討した。重 回帰分析の結果, 歩行速度に関連する身体機能の項目 は，注意機能を評価した TMT, 下肢筋力の指標とし た CS-30, バランス評価である開眼片脚立位時間の 3 項目であり，いずれも数值が高いほど歩行速度が速 かった。

注意力に関する先行研究では, 地域在住高齢者の通 常歩行と二重課題条件下での歩行パラメータを比較す ると, 二重課題条件下での歩行速度と歩行率が有意に 低下したと報告 ${ }^{11)}$ されている。下肢筋力については, 
表 1 対象者の属性・歩行パラメータ・身体機能の測定值 $(n=96)$

\begin{tabular}{|c|c|c|c|c|c|}
\hline \multicolumn{2}{|c|}{ 属性 } & \multicolumn{2}{|c|}{ 歩行パラメータ } & \multicolumn{2}{|l|}{ 身体機能 } \\
\hline 年齢(歳) & $73.7 \pm 5.7$ & 歩行速度 $(\mathrm{cm} / \mathrm{sec})$ & $171.5 \pm 28.0$ & 上体起こし（回） & $8.0 \pm 5.9$ \\
\hline 身長 $(\mathrm{cm})$ & $150.8 \pm 5.9$ & 歩幅（cm） & $63.4 \pm 8.3$ & 握力 $(\mathrm{kg})$ & $22.4 \pm 4.1$ \\
\hline 体重 $(\mathrm{kg})$ & $49.6 \pm 8.7$ & ストライド $(\mathrm{cm})$ & $126.9 \pm 16.5$ & 大腿四頭筋筋力 $(\mathrm{kg})$ & $21.1 \pm 4.1$ \\
\hline & & 立脚時間（sec） & $0.5 \pm 0.1$ & 足趾把持力 (kg) & $6.0 \pm 2.9$ \\
\hline & & 遊脚時間（sec） & $0.3 \pm 0.0$ & CS-30（回） & $19.2 \pm 5.6$ \\
\hline & & 両脚支持時間 (sec) & $0.1 \pm 0.0$ & 長座体前屈距離（cm） & $36.4 \pm 8.5$ \\
\hline & & 歩隔 $(\mathrm{cm})$ & $7.0 \pm 2.8$ & 開眼片脚立位時間（sec） & $34.0 \pm 34.6$ \\
\hline & & 歩行角度（） & $6.5 \pm 2.8$ & TMT (sec) & $119.7 \pm 40.8$ \\
\hline & & つま先角度（ㅇ & $2.7 \pm 4.3$ & & \\
\hline
\end{tabular}

平均值 \pm 標準偏差

CS-30: 30-second chair-stand test

TMT: Trail Making Test

表 2 各歩行パラメータを従属変数とした重回帰分析

\begin{tabular}{|c|c|c|c|c|c|c|}
\hline \multirow{2}{*}{ 従属変数 } & \multirow{2}{*}{ 説明変数 } & \multirow{2}{*}{ 標準偏回帰係数 } & \multicolumn{2}{|c|}{ 95\%信頼区間 } & \multirow{2}{*}{ 有意確率 } & \multirow{2}{*}{ VIF } \\
\hline & & & 下限 & 上限 & & \\
\hline \multirow[t]{3}{*}{ 歩行速度 } & TMT & -0.343 & -0.344 & -0.090 & $<0.001$ & 1.069 \\
\hline & CS-30 & 0.231 & 0.221 & 2. 209 & 0.017 & 1. 037 \\
\hline & 開眼片脚立位時間 & 0.221 & 0.021 & 0.313 & 0.025 & 1.076 \\
\hline \multicolumn{7}{|l|}{ （調整済み $\mathrm{R}^{2}=0.294 ）$} \\
\hline \multirow[t]{3}{*}{ 歩幅 } & 長座体前屈距離 & 0.250 & 0.051 & 0.445 & 0.014 & 1.122 \\
\hline & 身長 & 0.285 & 0.139 & 0.722 & 0.004 & 1. 064 \\
\hline & CS -30 & 0.270 & 0.121 & 0.730 & 0.007 & 1. 059 \\
\hline \multicolumn{7}{|c|}{ （調整済み $\mathrm{R}^{2}=0.280 ）$} \\
\hline \multirow[t]{3}{*}{ ストライド } & 長座体前屈距離 & 0.250 & 0.102 & 0.890 & 0.014 & 1.122 \\
\hline & 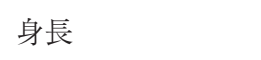 & 0.285 & 0.276 & 1. 444 & 0.004 & 1.064 \\
\hline & CS-30 & 0.270 & 0.242 & 1. 460 & 0.007 & 1. 059 \\
\hline \multicolumn{7}{|l|}{ （調整済み $\mathrm{R}^{2}=0.280 ）$} \\
\hline \multirow[t]{2}{*}{ 両脚支持時間 } & 年齢 & 0.265 & 0.000 & 0.002 & 0.009 & 1.012 \\
\hline & 体重 & 0.214 & 0.000 & 0.001 & 0.035 & 1.010 \\
\hline \multicolumn{7}{|l|}{ （調整済み $\mathrm{R}^{2}=0.205 ）$} \\
\hline \multirow[t]{2}{*}{ 歩行角度 } & 身長 & -0.316 & -0.242 & -0.053 & 0.003 & 1.000 \\
\hline & CS-30 & -0.213 & -0.202 & -0.005 & 0.040 & 1.000 \\
\hline （調整済み $\mathrm{R}^{2}=0.144 ）$ & & & & & & \\
\hline
\end{tabular}

※ステップワイズ法によって抽出された項目

TMT: Trail Making Test

CS-30: 30-second chair-satand test

CS-30を虚弱高齢者用に修正した Frail CS-10の回数 が多いほど歩行速度が速いとの報告(4゙ある。また南 條ら ${ }^{12}$ は, 歩行速度と等尺性膝伸展筋力がともに良好 な高齢者では，とくに開眼片脚立位時間が歩行速度に 影響を与えたと報告している。本研究でも, 地域在住 女性高齢者の注意力, 下肢筋力, バランス能力が高い ほど歩行速度が速いことが示され，先行研究と矛盾し ない。

歩幅とストライドの影響因子として抽出されたのは
長座体前屈距離, 身長, CS-30の 3 項目であり, いず れも数值が高いほど歩幅とストライドが大きいという 関係が示された。先行研究では, 膝窩部をストレッチ することで歩行速度が即時的に改善すると報告されて おり ${ }^{13)}$ ，柔軟性が歩幅やストライドに影響を与えるこ とが示唆される。また，身長 ${ }^{14)}$ や大腿四頭筋筋力 ${ }^{15}$ が 歩幅に関与することも明らかにされており ${ }^{3)}$, 本研究 においても先行研究を追認した。

両脚支持時間の影響因子として抽出されたのは，年 
齢と体重の 2 項目であり, 年齢が高く体重が重いほど 両脚支持時間が長いという関係が認められた。先行研 究では若年者に比べ高齢者は両脚支持期の割合が大き く，加齢の要因が影響する ${ }^{16,17)}$ と報告されている。ま た体重の０～60\%の重りを背部に装着して歩行した場 合, 両脚支持時間は体重の $60 \%$ の重りを付けた時に最 大となり，何も重りを付けなかった時に最小値となる ことが明らかにされている ${ }^{18)}$ 。本研究に打いても，年 齢が高く体重が重い高齢者ほどバランス能力が低下す るため ${ }^{19)}$ ，不安定な単脚支持時間を減少させて両脚支 持時間を延長させたものと推察した。

歩行角度を従属変数とすると, 身長と CS-30の 2 項 目が独立して関連する因子として抽出され，ともに数 值が低いほど歩行角度が増加することが認められた。 先行研究において, 歩行角度は歩幅と負の相関が認め られ，歩幅が減少すると歩行角度は増加することが示 されている ${ }^{18)}$ 。歩幅は身長と比例し ${ }^{14)}$, 歩幅と下肢筋 力には正の相関がある ${ }^{15)}$ 。したがって身長が低い，ま たは下肢筋力が低下している高齢者は, 歩幅が減少し 歩行角度が増加した可能性が考えられる。

これらの結果から, 下肢筋力の指標としたCS-30, バランス能力の指標とした開眼片脚立位時間, 柔軟性 の指標とした長座体前屈距離, および注意機能の指標 としたTMT を改善することで, 地域在住女性高齢者 の歩行能力の維持・向上を図れる可能性が示された。 これまでの研究において, 下肢筋力 ${ }^{4)}$ ・バランス能

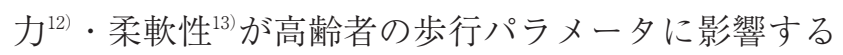
ことが報告されている。本結果は, 高齢者の最速歩行 には身体機能だけでなく注意機能も関係していること を示唆したものであり, 注意機能への介入の重要性が 示された。

ただし，本研究は女性のみを対象とした横断調查で あり, 歩行パラメータと関連があった身体機能や注意 機能を改善することで, 高齢者の歩行能力が改善でき るかは明らかにできていない。また, 重回帰分析によっ て抽出された各変数の標準偏回帰係数, ならびに決定 係数の值が高值ではなく, 説明力が十分ではないこと が本研究の限界である。今後は, 本研究で歩行パラメー 夕と関連が認められた下肢筋力, 柔軟性, バランス能 力, 注意機能に介入することで, 歩行パラメータが改 善するか否かについて縦断的に検討する必要がある。

\section{引用文献}

1) Ribom EL, Grundberg E, Mallmin H, et al.: Estimation of physical performance and measurements of habitual physical activity may capture men with high risk to fall-data from the Mr Os Sweden cohort. Arch Gerontol Geriatr, 2009, 49(1): 72-76.

2) 新開 省二, 熊谷 修, 渡辺修一郎 - 他 : 縦断研究からみ た地域老人の “閉じこもり”の特徵とその危険因子. J Epidemiol Suppl, 2000, 10(1): 52.

3 ) 大杉 紘徳, 村田 伸, 堀江 淳 - 他 : 地域在住高齢者の 各種歩行パラメータに関連する要因分析. ヘルスプロモー ション理学療法研究, 2014, 4 (1) : 31-35.

4 ) 高橋 佑太, 川島 拓馬, 廣田 千香 - 他 : 安定期慢性閉 塞性肺疾患患者における最大歩行速度の決定因子と予後予 測指標との関連. 日本呼吸ケア・リハビリテーション学会 誌, 2015, 25(2) : 218-221.

5 ) 文部科学省 : 新体力テスト実施要項 (65-79歳対象). http://www.mext.go.jp/component/a_menu/sports/detail /_icsFiles/afieldfile/2010/07/30/1295079_04.pdf（閲 覧日 2017/4/1)

6 ) 加藤 宗規, 山崎 裕司, 柊 幸伸・他：ハンドヘルドダ イナモメーターによる等尺性滕伸展筋力の測定－固定用べ ルトの使用が検者間再現性に与える影響一。総合リハビリ テーション, 2001, 29(11)：1047-1050.

7 ) 相馬 正之, 村田 伸, 甲斐 義浩 - 他: 足指把持力発揮 時における下腿筋の筋活動. 理学療法学科, 2013, 28(4)： 491-494.

8 ）中谷 敏昭, 灘本 雅一, 三村 寛一・他：日本人高齢者 の下肢筋力を簡便に評価する30秒椅子立ち上がりテストの 妥当性. 体育学研究, 2002, 47(5)：451-461.

9 ) 村田 伸, 大山 美智子, 大田尾 浩 - 他：地域在住高齢 者の足趾把持力に関する研究一性差および年代別の比較 理学療法科学, 2007, 22(4) : 499-503.

10）本田 哲三 : 注意障害と記憶障害の評価法, 高次脳機能障 害とリハビリテーション. J.of CLINICAL REHABILITATION 別冊高次脳機能障害のリハビリテーション, 1995 : $129-134$.

11）飯田 康平, 村田 伸, 井内 敏揮 - 他: 二重課題が地域 在住高齢者の歩行パラメータに及ぼす影響. ヘルスプロ モーション理学療法研究, 2016, 6 (3) : 127-131

12）南條 恵悟, 長澤 弘, 千葉 公太・他: 歩行速度と下肢 筋力の違いは足趾圧力と歩行速度 ・ バランス能力の関連性 に影響するか? 一入院高齢患者での検討一. 理学療法科 学, 2016, 31(1) : 151-155.

13）本間 秀文, 鈴木 博人, 櫻井 優 - 他 : 膝窩部持続伸張 が歩行に与える影響. 東北理学療法学, 2014, (26)：9598.

14）䈳長 謙良, 吉永 安俊, 趙 廷寧 : 身長と歩幅の相関に 関する一考察 - 学生の歩測の事例から一. 琉球大学農学部 学術報告, 1998, (45): 149-155.

15) Nakamura R, Hosokawa T, Tsuji I: Relationship of muscle strength for knee extension to walking capacity in patients with spastic hemiparesis. Tohoku J exp Med 1985, 145(3): 335-340.

16) Kaneko M, Morimoto $Y$, Kimura M, et al.:A kinematic analysis of walking and physical fitness testing in elderly 
women. Can J Sport Sci, 1991, 16(3): 223-228.

17) Murray MP, Kory RC, Clarkson BH: Walking patterns in health old men. J Gerontol, 1969, 24(2): 169-178.

18) Tomohiro Demura, Shin-ichi Demura : Relationship among Gait Parameters while Walking with Varying Loads. Journal of PHYSIOLOGICAL ANTHROPOLOGY, 2010, 29(1): 29-34

19) Spyropoulos P, Pisciotta JC, Pavlou KN, et al.: Biomechanical gaitanalysis in obese men. Arch Phys Med Rehabil 1991. 72(13): 1065-1070. 